\title{
Investigation of the Opinions of Science Teachers About Homework
}

\author{
Hamiyet $\operatorname{Sayan}^{1} \&$ Hatice Mertoğlu ${ }^{2}$ \\ ${ }^{1}$ Faculty of Health Sciences, Üsküdar University, Istanbul, Turkey \\ ${ }^{2}$ Science Education Department, Marmara University, Istanbul, Turkey \\ Correspondence: Hamiyet Sayan, Faculty of Health Sciences, Üsküdar University, Istanbul, Turkey. E-mail: \\ hamiyet.sayan@uskudar.edu.tr
}

Received: January 24, 2020 Accepted: February 28, 2020 Online Published: March 10, 2020

doi:10.5539/jel.v9n2p232 URL: https://doi.org/10.5539/jel.v9n2p232

\begin{abstract}
Despite the restrictions and controversies in Turkey's educational system, the efficacy of the homework assignments on the student's development is indisputable. Besides, what needs to be discussed is what kind of assignments should be given to students, and how they should be evaluated. The aim of this study is to investigate the views of science teachers about homework assignments. The survey method was preferred for this study. A questionnaire was developed by the researchers, and 100 teachers were reached online and via social media. The data obtained from the study were evaluated through quantitative and qualitative analyses. This study shows that the majority of the teachers do not support banning homework, and they consider it as necessary. Teachers mostly assign homework assignments for repetition and reinforcement. Project assignments and research presentation assignments are the most commonly assigned types of homework. Teachers give homework to students which they can do mostly at home spending $0-1$ hours together with their friends. According to the teachers, homework provides the most benefits for reinforcement, repetition and learning. In the study, it was found that the majority of the teachers did not use portfolios. According to the teachers participating in the study, the factors that mainly affect student motivation are concentration, reluctance and insufficient knowledge.

In order for students to develop their skills properly in the 21 st century and be successful in international examinations such as TIMSS, their understanding of homework must also change to meet the requirements of the age.
\end{abstract}

Keywords: science education, teacher opinions, homework, survey

\section{Introduction}

Rapid and significant changes occur in today's world. Information experiences rapid changes, and facts and events are examined through multidimensional rather than one-dimensional ways. It becomes preferable to learn the ways of accessing information rather than storing it and accepting it as immutable. In this case, it is increasingly needed to educate people with the skills that allow them to access information (Kutlu et al., 2009). These changes in the community needs and the fact that the existing assessment system is away from reaching students' real evaluations also makes it necessary to apply new measurement and evaluation tools and methods (Bahar et al., 2008). Therefore, homework assignments given to students must meet the requirements of the century and the student's needs.

In the literature, homework is defined in multiple ways. According to Hong et al. (2000), homework is one of the teaching practices frequently used in educational institutions. Özer and Öcal (2012) defined homework as one of the most frequently used teaching methods by teachers. Barnes (2001) stated that homework is a common teaching strategy used by teachers all over the world. Cooper, Robinson and Patall (2006) defined homework as any task given by schoolteachers intended for students to work outside the school hours. According to another definition, homework assignments are exercises that are generally given to prepare students for the lesson, and mostly to repeat, expand and cover what is learned in the lesson in out-of-school times (Ergün \& Özdaş, 1997). According to Yuladır and Doğan (2009), homework is all of the activities given according to the needs of students, to conduct research and examination, to better understand the subjects covered in the lessons or to channel them to work on a subject. According to Güneş (2014), homework is an important activity for students to develop their mental, emotional, physical and social skills and keep them for life. 
When the historical process is analyzed, it is seen that homework is prominent in some periods and banned in some periods since it is accepted as redundant. In recent years, it has been deemed necessary to give performance-based homework and considered that homework contributes to students' academic success, helps develop various skills and provides lifelong learning (Güneş, 2014). Homework is applied in schools as a part of teaching. However, it is also a controversial topic. The benefits and harms of homework have been debated for a long time. How often and how many homework assignments will be given to students, how to evaluate them, how to give feedback to students about homework, etc. are all discussed in several studies. The importance given to homework increases or decreases in different time periods (EARGED, 2011).

Studies show that homework assignments have different effects in each teaching level (U.S. Department of Education, 2002). These effects are examined below as being positive or negative:

\subsection{The Positive Effect of Homework}

Babadoğan (1990) and Bayrakci (2007) stated that homework assignments help students develop positive attitude towards the lessons and to socialize. Additionally, there are studies stating that doing homework increases students' success (Glazer \& Williams, 2001; Gündoğan-Özben, 2006; Kaplan, 2006). The study conducted by Cooper, Robinson and Patall (2006) stated that homework has a positive effect on success. As it may be seen, studies have revealed that homework increases students' academic success. At the same time, the increase in the amount of homework is said to increase students' success (Cooper, 2006; McMullen, 2007).

Gedik, Altıntaş and Kaya (2018) stated that homework is among the factors affecting students' success in science. In their study, students stated that the homework given to them should prepare them for examinations. A study by Kaya and Kaya (2018) drew attention to the relationship between homework and students' science achievement. The researchers stated that the homework should be done in 30-60 minutes and given less frequently. They suggested that not assigning any homework or assigning homework continuously had a negative effect on science achievement. It shows that giving homework improves the performance of low-performing students or students attending low-performing schools. Thus, giving more homework may help bridge the gap in success between high- and low-performing students. In particular, it is stated that applying policies to increase the time students spend on their homework and the amount of homework are likely to increase the performance of low performing students and schools (McMullen, 2007). Another study (Yuladır \& Doğan, 2009) stated that homework contributes to the academic and social development of students. It is also known that homework helps connect old learning and new learning. According to learning theories, homework is one of the activities that provide active learning (Temel, 1989; Yıldırım et al., 2000). Homework plays an important role for the learning process in achieving goals. Homework is an effective method to teach students how to develop a scientific thinking and access to information resources, how to gain problem solving skills and how to establish cause and effect relationships (Yapıcı, 1995; Gür, 2003; Yıldırım et al., 2000). Sullivan and Sequeira (1996) suggested that homework indicates that students can improve their working skills and critical thinking skills and that learning can also occur out of school. It is emphasized that homework is an important tool for developing responsibility and acts as a bridge between the school and the family (Güneş, 2014).

As it may be seen from the aforementioned studies, homework positively affects students' attitudes, achievements and social development.

\subsection{Negative Effect of Homework}

Various sources mention limitations of homework and, in some cases, their harm besides the benefits of homework assignments. According to Pope (2014), it is not guaranteed that students will learn well by doing homework, will like to do homework and will benefit from it. It was stated that students do homework to get higher grades. The researcher's wide-ranging research resulted in the conclusion that too much homework affects students badly, even causing physical discomfort and isolating them from life. They found that, even in high-achieving schools, doing more than 2 hours of homework on the high school level causes conditions such as stress and physical ailments, sleep disturbances, depression and getting away from social activities. Additionally, it was concluded that excessive homework does not facilitate learning and reduces self-confidence even in older students. There seems to be a paradox in this regard. Kohn (2006) stated that students feel homework as pressure, and it steals from sleep and development of other social skills.

Yuladır and Doğan (2009) stated problems in students' homework performances in the science class, and students did not show the needed attention to homework. The study conducted by Demirbaş (2011) with teachers working in rural areas determined that they experienced trouble in homework assignments. It was revealed that teachers thought negatively about homework due to societal conditions. In a study conducted by Ersoy and Anagün, it was seen that science teachers expressed some problems such as internet usage related to homework, 
parents' indifference to homework and differing participation levels to group homework assignments (2009). In the research conducted by Balbağ et al. with science teachers, negligence and inattention of students about doing homework were reported among problems (2016).

A comprehensive research in Turkey found that homework assignments have both positive and negative effects on students' attitudes towards schools, teachers and courses. Research stated that the quality of the homework assignments and the teacher's attitudes are the main determinants of this. As a result, the way that homework affects the student depends on the teachers (Demirbaş, 2011).

In this study, it was aimed to reach findings that would be used to reveal the views of science teachers about homework and contribute to the solution of homework-related problems.

\section{Method}

\subsection{Model of the Study}

The survey model was applied in this study. Studies conducted on larger groups compared to other types of studies, in which the opinions of the participants about a subject or features such as interest, skill, ability and attitude are determined, are called survey studies (Büyüköztürk, Çakmak, Akgün, Karadeniz, \& Demirel, 2011). Karasar (2013) stated that survey models are research approaches that aim to describe a situation as it is, whether it had existed in the past or still exists (Karasar, 2013, p. 81). This study was a survey study since the data obtained reflected the opinions of teachers.

\subsection{Participant (Subject) Characteristics}

Science teachers constituted the sample of the study. Readily accessible convenience sampling, which is one of the purposive sampling methods, was used in determining the participants. The demographic characteristics of the teachers who participated in the study are presented in Table 1 below.

Table 1. Frequency distributions related to the teachers' demographic characteristics $(\mathrm{N}=100)$

\begin{tabular}{lll}
\hline Variable & Group & $\boldsymbol{f}$ \\
\hline Gender & Female & 83 \\
Age & Male & 17 \\
& $21-25$ & 26 \\
& $26-30$ & 44 \\
& $31-35$ & 19 \\
Education level & $36-40$ and above & 11 \\
Faculty & Undergraduate & 66 \\
& Graduate/PhD & 34 \\
Graduated department & Faculty of Education & 96 \\
& Faculty of Arts and Sciences & 4 \\
Number of students & Science & 91 \\
& Other & 9 \\
& 24 and below & 43 \\
& $25-34$ & 32 \\
& 35 and above & 25 \\
\hline
\end{tabular}

\subsection{Data Collection Tool}

A questionnaire developed by the researchers called "Examination of the views of science teachers about homework" was used. In the questionnaire form, there were 22 open-ended and closed-ended questions to collect the teachers' demographic information and views about homework. With these questions, the necessity of homework, types of homework, place where the homework will be done, time allocated to homework, people who participate in doing homework, benefits of homework, homework and student motivation, evaluation of homework and contribution to final grades were investigated. In the process of developing the questionnaire, firstly, the literature was reviewed by the researchers, and a question pool was created. The perceivability of the questions by the participants was then examined by a pilot study. The questionnaire was finalized after the necessary arrangements. The questionnaire applied via Google Forms was sent to the participants via e-mail and social media on the internet and was collected in 2 months.

\subsection{Analysis of the Data}

Descriptive and content analysis methods were used to analyze the data obtained from the questionnaire. 
Percentage (\%) and frequency (f) techniques were used to describe the demographic information and the data obtained from the closed-ended questions. To analyze the rest of the questionnaire, the content analysis method was used. The general process in content analysis follows gathering data which are similar within the frameworks of certain concepts and themes and organizing and interpreting them in a way that the reader can understand (Yıldırım \& Şimşek, 2013). With content analysis, two experts coded the data obtained from the opinions of science teachers about homework by determining themes, and frequencies (f) were calculated. The reliability of the data was calculated with the formula [Agreement / (Agreement + Disagreement)] x 100 proposed by Miles and Huberman (1994). In the study, the percentage of agreement in coding was calculated as 85\% using this formula. According to Yıldırım and Şimşek (2013), when the agreement percentage in a reliability calculation is $70 \%$, the reliability percentage is considered to be reached. Therefore, the values obtained indicated that the coding reliability of the researchers was sufficient.

\section{Results}

According to the data obtained from the opinions of the teachers who participated in the study about homework, 8 themes, namely "the necessity of the homework", "the types and characteristics of the homework", "the place where the homework is done", "the time allocated to the homework", "the people who do the homework together", "the benefits of the homework", "the evaluation of the homework", "homework and motivation", were created and are presented below.

\subsection{The Necessity of the Homework}

Table 2. Teachers' views on the necessity of the homework

\begin{tabular}{ll}
\hline The necessity of the homework & $\mathrm{f}$ \\
\hline Necessary & 94 \\
Unnecessary & 6 \\
& 100 \\
\hline
\end{tabular}

In Table 2, it is seen that the majority of the teachers ( $f=94)$ assumed homework to be necessary. When the teachers were asked to explain the rationale of their views on the necessity of homework, they made the explanations shown in Table 3.

Table 3. Rationales on the necessity of homework

\begin{tabular}{llll}
\hline $\begin{array}{l}\text { Rationales of the teachers who consider } \\
\text { homework necessary }\end{array}$ & f & $\begin{array}{l}\text { Rationales of the teachers who consider homework } \\
\text { unnecessary }\end{array}$ \\
\hline Repeating for reinforcement & 53 & May differ by the topic & f \\
For research purposes & 7 & It has little effect on students' achievements \\
Individual learning & 10 & Not necessary for every course and topic \\
Motivation & 4 & Must be based on student request & 1 \\
Responsibility & 5 & Cause student to be tired \\
Permanent learning & 10 & It is not effective in gains, it is an extra burden to the student \\
Insufficient lesson hours & 2 & & \\
Preparation for the lesson, preliminary knowledge & 3 & & \\
Total & 94 & & \\
\hline
\end{tabular}

Table 3 shows that the teachers who considered homework necessary ( $f=53$ ) mostly gave homework for reinforcement purposes.

Table 4. Teachers' views on removal of homework in new programs $\backslash$

\begin{tabular}{llll}
\hline Teachers' views on removal of homework in new programs & f & \% \\
\hline Should not be removed & Should not be removed & 58 & 83 \\
& Should not be removed but should not be too much & 25 & \\
& Should be removed & 9 & 9 \\
& Undecided & 8 & 8 \\
& Total & 100 & 100 \\
\hline
\end{tabular}


Table 4 shows that the majority of the teachers $(f=83)$ thought that homework should not be removed from the program.

\subsection{The Types and Characteristics of the Homework}

Table 5. The types of the homework given to the students

\begin{tabular}{lll}
\hline The types of the homework given to the students & f & $\mathbf{\%}$ \\
\hline Projects & 75 & 14 \\
Research and presentation homework assignments & 68 & 13 \\
Worksheets & 63 & 12 \\
Homework assignments from the textbook & 63 & 12 \\
Test solving & 61 & 12 \\
In-class assignments & 58 & 11 \\
Experiments, observations, etc. & 51 & 10 \\
Extracurricular homework assignments & 34 & 7 \\
Selected products file (portfolios) & 24 & 5 \\
Homework assignments for reading and writing & 23 & 4 \\
Total & $520^{*}$ & 100 \\
\hline
\end{tabular}

Note. *Frequency of teacher expressions.

Table 5 shows that the teachers mostly gave project assignments (14\%). Then, they gave research and presentation $(13 \%)$, textbook (12\%), worksheets $(12 \%)$ and test solving (12\%) assignments.

Table 6. Status of giving students a performance assignment

\begin{tabular}{ll}
\hline Status of giving students a performance assignment & f \\
\hline Gives a performance assignment & 65 \\
Does not give a performance assignment & 35 \\
& 100 \\
\hline
\end{tabular}

Table 6 shows that the majority of the teachers $(f=65)$ gave performance assignments to their students.

Table 7. Ensuring the online resource reliability of research papers

\begin{tabular}{llll}
\hline Ensuring the reliability of online resources & f & Total \\
\hline The online resource reliability is being & I am offering the online resource addresses & 38 & 73 \\
checked & I am asking for bibliography & 23 & \\
& Asking for various resources & 11 & \\
& Data check & 1 & \\
& Does no check resources & 14 & 14 \\
& Does not allow internet resources & 13 & 13 \\
& & 100 & 100 \\
\hline
\end{tabular}

It may be seen in Table 7 that the majority of the teachers $(f=73)$ provided the reliability of the online addresses of resources of research assignments.

\subsection{The Place Where the Homework is Done}

Table 8 . The place where the student will do the homework

\begin{tabular}{lll}
\hline The place where the student will do the homework & $\mathbf{f}$ & $\mathbf{\%}$ \\
\hline At home & 89 & 35 \\
In class & 48 & 19 \\
Unstructured environment & 42 & 17 \\
Online & 36 & 14 \\
Out-of-school institutions and organizations & 33 & 13 \\
Other & 4 & 2 \\
Total & $252^{*}$ & 100 \\
\hline
\end{tabular}

Note. *Frequency of teacher expressions. 
Table 8 shows that the teachers gave homework to the students that they will do mostly at home (35\%).

\subsection{The Time Allocated to the Homework}

Table 9. Time given to do homework

\begin{tabular}{lll}
\hline Time given to do homework & f & \% \\
\hline $0-1$ hours & 76 & 53 \\
$1-2$ hours & 30 & 21 \\
2 hours and more & 5 & 4 \\
in a long period & 32 & 22 \\
Total & $143^{*}$ & 100 \\
\hline
\end{tabular}

Note. *Frequency of teacher expressions.

Table 9 shows that the teachers gave homework to the students to do between 0 hours and 1 hour at most (53\%). Then, they gave homework that the students would do in a long period (22\%) and in 1-2 hours (21\%).

\subsection{The People Who Do the Homework Together}

Table 10. The people who the students do the homework together

\begin{tabular}{lll}
\hline fobidhe people who the students do the homework & $\mathbf{\%}$ \\
\hline Friends & 85 & 34 \\
By oneself & 74 & 29 \\
Family & 52 & 21 \\
Specialists or other persons relevant to the subject & 35 & 14 \\
Other & 4 & 2 \\
Total & $250^{*}$ & 100 \\
\hline
\end{tabular}

Note. *Frequency of teacher expressions.

Table 10 shows that the teachers mostly gave homework to students that they would do together with their friends (34\%). Then, they gave homework that the students would do alone, together with their families and by specialists or people relevant to the subject.

\subsection{The Benefits of the Homework}

Table 11. The benefits of the homework

\begin{tabular}{lll}
\hline The benefits of the homework & f & $\mathbf{\%}$ \\
\hline Reinforcement & 34 & 27 \\
Repeating & 30 & 23 \\
Learning & 30 & 23 \\
Responsibility & 13 & 10 \\
Research & 6 & 5 \\
Motivation & 7 & 6 \\
Personal development & 7 & 6 \\
Total & $127 *$ & 100 \\
\hline
\end{tabular}

Note. *Frequency of teacher expressions.

Table 11 shows that homework provided benefits such as reinforcement (27\%), repetition (23\%) and learning (23\%) according to the participants. 


\subsection{The Evaluation of the Homework}

Table 12. The way teachers evaluate the homework assignments and the reasons for not evaluating them

\begin{tabular}{llll}
\hline Evaluating homework assignments & Rationale & Yes & Total \\
\hline Evaluates & By rubric & 37 & 94 \\
& In details & 20 & \\
& According to the answers & 15 & \\
& Giving plus or minus & 10 & \\
& Quickly & 9 & \\
& No comment & 3 & 6 \\
& To make it fun & 1 & \\
& Unnecessary & 1 & \\
& Workload is increasing & 1 & \\
& No comment & 3 & \\
& & 100 & \\
\hline
\end{tabular}

Table 12 shows that the teachers participating in the research were asked whether they evaluated their homework, and 94 of them stated that they did, while 6 stated they did not. When asked about the rationale for these opinions, they gave different answers shown in Table 12.

Table 13. Whether or not to use and evaluate a selected works file (portfolio)

\begin{tabular}{llll}
\hline & & f & Total \\
\hline Usage and evaluation of a selected works file & By rubric & 20 & 33 \\
(portfolio) & According to presentation & 3 & \\
& Seldom & 3 & \\
& According to their development & 2 & \\
& No comment & 5 & \\
& Not using & 67 & 67 \\
& & 100 & 100 \\
\hline
\end{tabular}

Table 13 shows that most of the teachers $(f=67)$ did not use a portfolio. Of the teachers using portfolios $(f=33)$, 20 teachers evaluated homework with rubrics.

Table 14. Checking of the homework, evaluation and their contribution to the class scores

\begin{tabular}{llll}
\hline & Yes & No & Total \\
\hline Checking of the homework & 99 & 1 & 100 \\
Evaluating the homework & 95 & 5 & 100 \\
Using rubrics while evaluating homework assignments & 71 & 29 & 100 \\
Developing rubric for homework & 63 & 37 & 100 \\
Contribution of the homework to the school report & 82 & 18 & 100 \\
\hline
\end{tabular}

Table 14 shows that 99 teachers checked homework assignments, and 95 teachers evaluated them. 71 teachers used rubrics while evaluating homework assignments, and 62 teachers developed rubrics themselves. 82 teachers stated that homework contributed to the final school report.

\subsection{Homework and Motivation}

Table 15. Situations that affect student motivation in doing homework

\begin{tabular}{lll}
\hline Situations that affect student motivation in doing homework & f & $\mathbf{\%}$ \\
\hline Concentration & 70 & 26 \\
Reluctance & 63 & 23 \\
Insufficient knowledge & 62 & 22 \\
The ability to be organized & 33 & 12 \\
Fear & 29 & 11 \\
Financial difficulties & 17 & 6 \\
& $274^{*}$ & 100 \\
\hline
\end{tabular}

Note. *Frequency of teacher expressions. 
Table 15 shows that the most effective factor on student motivation was concentration (26\%). Reluctance (23\%) and insufficient knowledge (22\%) followed it.

\section{Discussion}

The survey method was used in this study to investigate the opinions of science teachers about homework. The opinions of 100 teachers who participated the survey were analyzed in quantitative and qualitative terms.

The main findings of study were as follows: while there were teachers who found it unnecessary to give homework assignments, the great majority of the teachers did not support removal of homework and thought that homework assignments are useful and necessary. The teachers mostly assigned homework for repetition and reinforcement purposes. Most of the teachers gave project assignments and research presentations as homework assignments. The teachers give online research homework and ensured the resource reliability. The science teachers who participated in the study gave homework to students which they could do mostly at home spending $0-1$ hour(s) together with their friends. According to the teachers, homework provides the most benefits for reinforcement, repetition and individual learning. In the research, it was found that the majority of the teachers did not use portfolios. The teachers evaluated the homework assignments with rubrics, and these evaluations contribute to the report score. The situations that affected student motivation were concentration, reluctance and insufficient information.

In the study conducted by Ergün and Duman (1998) on the same topic, it was stated that teachers considered students should do homework. In the research carried out by Ersoy and Anagün (2009), it was reported that science teachers gave homework for the purposes of preparation for the lesson, repeating and reinforcement and developing awareness of responsibility. Gedik, Altıntaş and Kaya (2018) stated that the homework is one of the factors affecting students' success in Science. In their study, they suggested that the homework to be given to the students should help them be prepared for examinations. While homework assignments aiming at examination success are preferred as being profitable in terms of motivation, Delaney (2017) stated that this preference causes ignoring of the actual benefits of research. In a study by Kaya and Kaya (2018), the relationship between homework and students' science achievement was examined. The researchers stated that homework should be done in a way that can be completed in 30-60 minutes and be given less frequently. Giving no homework or giving assignments permanently has a negative effect on achievement in science courses. In a study conducted by Özdemir (2015), it was noted that there is a significant positive relationship between the time allocated for homework and school burnout. It was stated that homework provides students with practical skills and time management skills (Ekici, 2014). It may be stated that the results of our research were in parallel with some of these studies.

In the literature, researchers provided different opinions about how homework should be given. According to Sallee and Rigler (2008), the homework should not be compulsory, routinized and should be aimed at achieving a specific goal. Other researchers (Çetinkaya, 1992; Hong et al., 2000; Gür, 2003; Hizmetçi, 2007; Ersoy \& Anagün, 2009) stated that knowing the homework styles and assigning homework accordingly affect the success of the student. Since assigning homework assignments according to the individual differences of students may contribute to the development of the students, these issues should be considered seriously.

The Education System is also in confusion on the issue of homework in Turkey. In 2006, a change was made in the regulation of primary schools, and performance assignments were defined (Official Gazette, 2006). This definition was changed in 2007 to performance tasks (Official Gazette, 2007). According to this definition, it is seen that performance tasks are not the work done at home, they are studies conducted under teacher guidance (Demirbaş, 2011). Performance tasks are activities that provide students with problem instances they may encounter in real life and require high-level mental skills. However, homework and performance tasks have different purposes. While homework assignments aim to repeat and reinforce what students learn in the lesson, performance tasks aim to use this learned information in their life and reach new information (Demirbaş, 2011). In accordance with the constructivist approach in the science curriculum in Turkey, it would be more beneficial to use performance tasks.

In line with the results obtained from this study, it may be stated that the understanding of homework should change in the 21 st century with changing curricula and developing technology. It is recommended to give homework that will contribute to students' success and development and will help develop research and responsibility awareness instead of forcing them.

\section{References}

Babadoğan, C. (1990). Ev Ödevlerinin Eğitim Programları İçindeki Yeri. Ankara Üniversitesi Eğitim Bilimleri 
Fakültesi Dergisi, 23(2). https://doi.org/10.1501/Egifak_0000000783

Bahar, M., Nartgün, Z., Durmuş, S., \& Biçak, B. (2008). Geleneksel-alternatif ölçme ve değerlendirme öğretmen el kitabı. Ankara: PegemA Yayıncılık.

Balbağ, M. Z., Leblebicier, K., Karaer, G., Sarkahya, E., \& Erkan, Ö. (2016). Türkiye'de fen eğitimi ve öğretimi sorunları. Eğitim ve Öğretim Araştırmaları Dergisi, 5(3), ISSN: 2146-9199.

Barnes S. (2001). Ladder to learning or stairway to stress: a study of grade 4 homework practices. Master of Education Thesis, University of Prince Edward Island, Canada.

Bayrakçı, Ö. (2007). İlköğretim Sosyal Bilgiler Dersindeki Araştırma Ödevlerinin (Etkinlik, Performans, Proje) Öğrencilerin Sosyalleşmesine Katklsı. M.A. Thesis. Sakarya Üniversitesi Sosyal Bilimler Enstitüsü, Sakarya. Retrieved from https://dergipark.org.tr/tr/pub/cankujlaw/issue/4026/53173

Büyüköztürk, Ş., Kılıç-Çakmak, E., Akgün, Ö. E., Karadeniz, Ş., \& Demirel, F. (2011). Bilimsel araştırma yöntemleri (20th ed.). Ankara: Pegem Akademi.

Çetinkaya, A. (1992). Adana il merkez ortaokullarında ev ödevlerine ilişskin karşılaşılan sorunlar. Unpublished M.A. Thesis. Çukurova University, Institute of Social Sciences, Adana.

Cooper, H. (2006). The Battle Over Homework: Comman Ground for Administrators, Teacher, and Parents (3rd ed.). Thousand Oaks, CA: Corwin Press. https://doi.org/10.4135/9781483329420

Cooper, H., Robinson, J. C., \& Patall, E. A. (2006). Does homework improve academic achievement? A synthesis of research, 1987-2003. Review of Educational Research, 76(1), 1-62. https://doi.org/10.3102/00346543076001001

Delaney, S. (2017). Become the primary teacher everyone wants to have: a guide to career success. London and NewYork: Routhledge, NY10017. https://doi.org/10.4324/9781315560571

Demirbaş, A. (2011). İlköğretim okullarındaki (1-5. sinif) ödev uygulamalarının değerlendirilmesi. Ankara. Retrieved from http://www.meb.gov.tr

EARGED. (2011). Millî eğitim bakanlı̆̆ ĕgitimi araştırma ve gelişstirme dairesi başkanlı̆̆ ilköğretim okullarındaki (1-5. sinıf) ödev uygulamalarının değerlendirilmesi araştırmast. Ankara. Retrieved from http://www.meb.gov.tr

Ekici, F. T. (2014). Elementary school students' views on the homework given in science courses. Educational Research and Reviews, 9(17), 594-605. https://doi.org/10.5897/ERR2014.1809

Ergün, M., \& Duman, T. (1998). Kritik durumlarda öğretmen davranışları. Millî Eğitim Dergisi, 137, 45.

Ergün, M., \& Özdaş, A. (1997). Öğretim İlke ve Yöntemleri. Nadir Kitap, İstanbul.

Ersoy, A., \& Anagün, Ş. S. (2009). Sınıf öğretmenlerinin fen ve teknoloji dersi ödev sürecine ilişkin görüşleri. Necatibey Eğitim Fakültesi Elektronik Fen ve Matematik Ĕgitimi Dergisi, 3(1), 58-79.

Gedik, N., Altintas, E., \& Kaya, H. (2018). Fen ve teknoloji dersinde verilen ev ödevleri hakkındaki öğrenci görüşleri. Journal of European Education, 1(1), 6-13.

Glazer, T. N., \& Williams, S. (2001). Averting the Homework Crisis. Educational Leadership, 58(7), 43-45.

Gündoğan-Özben, B. (2006). İlköğretim ikinci kademe öğrencilerinin fen bilgisi dersindeki başarllarına ev ödevi çalışmalarının etkisi. Unpublished M.A. Thesis. Gazi University, Institute of Educational Sciences Ankara.

Güneş, F. (2014). Eğitimde ödev tartışmaları. Bartın Üniversitesi Eğitim Fakültesi Dergisi, 3(2), 1-25. https://doi.org/10.14686/BUEFAD.201428169

Gür, H. (2002). Ev Ödevi yapma stillerinin akademik başartya etkisi. Retrieved from http://www.matder.org.tr/ev-odevi-yapma-stillerinin-akademik-basariya-etkisi/

Hizmetçi, S. (2007). İlköğretim 5. sını öğrencilerinin ödev stilleri ile akademik başarlları arasındaki ilişkinin incelenmesi. Unpublished M.A. Thesis. Çukurova University, Institute of Social Sciences, Adana.

Hong, E., \& Milgram, R. M. (2000). Homework: Motivation and Learning Preferance. Bergin and Garvey. Greenwood Publishing Group.

Kaplan, B. (2006). Illköğretim 6. sınıf "Yaşamımızı Yönlendiren Elektrik" ünitesinde ev ödevi verilmesinin ögrenci başarısina ve kavram ögrenmeye etkisi. Unpublished M.A. Thesis. Marmara University, Institute of Educational Sciences, Istanbul 
Karasar, N. (2013). Bilimsel araştırma yöntemi. Ankara: Nobel yayın.

Kaya, V. H., \& Kaya, E. (2018). Fen başarısını artırmak için ödevler ve kurslar gerekli midir? Anadolu Ögretmen Dergisi, 2(1), 48-62.

Kohn, A. (2006). The homework myth: Why our kids get too much of a bad thing. Cambridge, MA, US: Da Capo Press.

Kutlu, Ö., Doğan, C. D., \& Karakaya, İ. (2009). Öğrenci başarısının belirlenmesi: Performansa ve portfolyoya dayal durum belirleme. Pegem Akademi.

McMullen, S. (2007). The impact of homework time on academic achievement. The University of North Carolina at Chapel Hill. Retrieved from https://www.researchgate.net/publication/228958051_The_impact_of_homework_time_on_academic_achie vement

Miles, M. B., \& Huberman, A. M. (1994). Qualitative data analysis: A sourcebook of new methods. Newbury Park, CA: Sage.

Özdemir, Y. (2015). Ortaokul öğrencilerinde okul tükenmişliği: Ödev, okula bağll1ık ve akademik motivasyonun rolü. Adnan Menderes Üniversitesi Eğitim Fakültesi Eğitim Bilimleri Dergisi, 6(1), 27-35.

Özer, B., \& Öcal, S. (2012). ilköğretim 4. ve 5. sinif öğrencilerinin ev ödevlerine yönelik tutumlarının değerlendirilmesi. Dicle University Journal of Ziya Gokalp Education Faculty, 18, 1-16.

Pope, D. (2014). Nonacademic effects of homework in privileged, high schools. Journal of Experimental Education.

Sallee, B., \& Rigler, N. (2008). Doing our homework on homework: how does homework help? English Journal, 98(2), 46-51.

Sullivan, M. H., \& Sequeira, P. V. (1996). The impact of purposeful homework on learning. The Clearing House, 69(6), 646-348. https://doi.org/10.1080/00098655.1996.10114337

Temel, A. (1989). Öğrenci ödevleri bilinçli verilmeli. Çă̆daş Ĕ̆itim Dergisi, 140, $12-14$.

U.S. Department of Education. (2002). Homework tips for parents. Review of Educational Research, 76(1), 1-62. https://doi.org/10.3102/00346543076001001

Yapıcı, N. (1995). İlkokullarda öğretmen, ögrenci ve velilerin ev ödevleri konusundaki görüşlerinin belirlenmesi. Unpublished M.A. Thesis. Ankara University, Institute of Social Sciences, Ankara.

Yıldırım, A., Doğanay, A., \& Türkoğlu, A. (2000). Okulda başarı için ders çalışma ve öğrenme yöntemleri. Ankara: Seçkin Yayınevi.

Yıldırım, A., \& Şimşek, H. (2013). Sosyal bilimlerde nitel araştırma yöntemleri. Ankara: Seçkin Yayıncılık.

Yuladır, C., \& Doğan, S. (2009). Fen ve teknoloji dersinde öğrencilerin ev ödevi performansını arttırmaya yönelik bir eylem araştırması. Journal of Arts and Sciences, 12(2), 211-238.

\section{Copyrights}

Copyright for this article is retained by the author, with first publication rights granted to the journal.

This is an open-access article distributed under the terms and conditions of the Creative Commons Attribution license (http://creativecommons.org/licenses/by/4.0/). 